\title{
Clinical Radiological and Pathological Profile of Lung Cancer in a Tertiary Care Hospital in Telangana
}

\author{
Dr. Sravan Kumar ${ }^{1}$, Dr. B. Pani Kumarr", Dr. Hima Bindhu ${ }^{3}$
}

\author{
${ }^{1}$ Professor, Department of Respiratory Medicine, Kakatiya Medical College, Warangal, Rangam Peta Street, Telangana 506007, India \\ ${ }^{2}$ Associate Professor, Department of Respiratory Medicine, Kakatiya Medical College, Warangal, Rangam Peta Street, Telangana 506007, India \\ ${ }^{3}$ Post Graduate, Department of Respiratory Medicine, Kakatiya Medical College, Warangal, Rangam Peta Street, Telangana 506007, India
}

\author{
DOI: $10.36347 /$ sasjm.2020.v06i02.001 \\ | Received: 14.01 .2020 | Accepted: 30.01 .2020 | Published: 13.02 .2020 \\ *Corresponding author: Dr. B. Pani Kumar
}

Abstract

Original Research Article

Lung cancer is one of the most aggressive and prevalent type of malignancy causing high morbidity and mortality. The main aim of the study is to evaluate the clinical, radiological and pathological profile of lung cancer. Lung cancer was analysed in relation to age, sex and smoking history in 40 histologically diagnosed cases. The M:F ratio was 5:3.The common age group being 40-60 yrs. Smoking still remains to be the most common risk factor in pathogenesis of lung cancer according to this study. Most common radiological presentation was pleural effusion. Squamous cell carcinoma was the most frequent histopathological type followed by adenocarcinoma.

Keywords: Lung cancer, Tertiary care hospitals in Telangana.

Copyright @ 2020: This is an open-access article distributed under the terms of the Creative Commons Attribution license which permits unrestricted use, distribution, and reproduction in any medium for non-commercial use (NonCommercial, or CC-BY-NC) provided the original author and source are credited.

\section{INTRODUCTION}

Lung cancer is one of the leading causes of cancer related deaths in the world. The incidence of lung cancer is increasing in India and there is a need to understand the natural history of this disease. It is responsible for $28 \%$ of all the cancer related deaths [1]. In the developed countries, incidence and mortality from lung cancer in females is rising, whereas it is declining in males. Progressive survival extension and increasing cigarette smoking has led to a numerical rise of patients with primary lung cancer in India. It is in accordance with the epidemiological data from western countries, which shows rising prevalence of the disease in Indian population [2]. Smoking is the cause for more than $85 \%$ of the bronchogenic carcinoma cases [3, 4]. According to the world health organization (WHO) classification formulated in 1999; there are six major types of malignant epithelial non-small cell lung carcinoma (NSCLC) and small cell lung carcinoma (SCLC) [5]. The proportions of histopathological cell types of lung cancer vary with changes in social and other environmental factor [6].

\section{AIM OF THE STUDY}

To study the clinico- pathological- radiological profile of patients diagnosed with lung cancer from june2018 to nov 2019 at a tertiary care teaching hospital,warangal.

\section{MATERIALS AND METHODS}

In patient records of all patients admitted during the study period were examined and all patients with a histologically proven diagnosis of bronchogenic carcinoma were recruited.

Demographic characteristics, clinical, radiological and pathological details of each patient were recorded.

\section{RESULTS}

This study included 40 cases of histopathologically confirmed lung cancer. Out of which 25 cases were males and 15 cases were female. Mean age of the population was 58.35 yrs. Most common symptom was cough (27). Most common side involved was right side (23). Most common lobe involved was upper lobe (21). Most common histological subtype was squamous cell carcinoma (17). 25 cases were smokers.

\section{CONCLUSION}

This study has shown smoking as the principle risk factor in the causation of lung cancer among men. Primary lung cancer should always be suspected in a person presenting with unexplained cough of several weeks with other symptoms such as weight loss and 
fever with non resolving collapse-consolidation on chest radiograph. Further investigations should be carried out to rule out lung cancer, as most of the nonresolving pneumonias had been treated as tubercular pneumonias which lead to delay in the diagnosis of the cancer. This emphasized the need for more effective methods in the early diagnosis of lung cancer among general population.

\section{REFERENCES}

1. Beckett WS. Epidemiology and etiology of lung cancer. Clin Chest Med. 1993;14:1-15.

2. Ginsberg RJ, Vokes EE, Raben A. Cancer of the lung. In: DeVita VT, Hellman S, Rosenberg SA, editors. Cancer: Principles and practices of oncology. Philadelphia, PA: Lippincott-Raven; 1999; 849-950.

3. Carr DT, Holoye PY, Hong WK. Bronchogenic carcinoma. In: Murray JF, Nadal JA, editors. Textbook of respiratory medicine. 2nd ed. Philadelphia: WB Saunders Company; 1994; 1528-96.

4. Rosenow EC. Symposium on intrathoracic neoplasm, Proc. 1993;68:168-9.

5. Franklin WA. Diagnosis of lung cancer. Chest. 2000;117:80-9.

6. Travis WD, Colby TV, Corrin B. Histological typing of tumors of lung and pleura. In: Sobin LH, editor. World Health Organization. Classification of tumors. 3rd ed. Berlin: Springer-Verlag, 1999. 